Article

\title{
Coastal Innovation Paradox
}

\section{Bruce C. Glavovic}

Resource and Environmental Planning Programme, Massey University, Palmerston North, New Zealand; E-Mail: b.glavovic@massey.ac.nz; Tel.: +64-6-356-9099; Fax: +64-6-350-5737

Received: 20 December 2012; in revised form: 1 February 2013 / Accepted: 4 February 2013 / Published: 4 March 2013

\begin{abstract}
Coasts are the primary habitat for humanity. Throughout history, coastal cities and towns have been a crucible for innovation. However, business and technological innovations imperil coastal communities, because prevailing practices are unsustainable. Consequently, coasts are the frontline in humanity's endeavour to learn to live sustainably in the face of global change. Governance innovations have done little to stem the tide of unsustainable coastal activities. Paradoxically, innovation is necessary to navigate a way out of the vulnerability trap that past innovation has unwittingly set. This is the first of two articles that examine, in turn, the coastal innovation paradox and the coastal innovation imperative. This article explains the coastal problématique and innovation paradox. Then, the nature and dimensions of innovation are outlined. Notwithstanding wholesale innovations in governance and public sector management, the sustainability crisis is deepening. Why is it so difficult to mobilize effective collective action for coastal sustainability? Locating coastal management within the wider milieu of evolving and multi-layered governance helps to answer this question. Resolving the coastal innovation paradox necessitates coherent innovation across governance episodes, processes and cultures. The second article posits a transformative foundation of deliberative coastal governance to foster innovation and facilitate the transition to coastal sustainability.
\end{abstract}

Keywords: coastal innovation paradox; coastal sustainability; coastal management; deliberative coastal governance

\section{Introduction}

Coasts are the frontline in humanity's battle to learn to live sustainably on Earth. Past business and technological innovations have yielded rich rewards, but they have generated social and environmental 
impacts that imperil coastal livelihoods. Paradoxically, innovation is essential to escape the predicament created by past ingenuity and prevailing practices. This is the first of two articles that examines the coastal innovation paradox and imperative. This article first explains the coastal problématique and innovation paradox. Secondly, the nature and dimensions of innovation are outlined, with a focus on the distinguishing characteristics of governance (Governance is more than government and refers to the interactions of actors from the state, civil society and the private sector to solve societal problems through power sharing, social coordination and collective action (see Sections 3 and 4) innovation. Thirdly, the evolving character of governance and corresponding features of and opportunities for innovation are described. Past innovations in governance and public sector management have failed to stem the sustainability crisis. Locating coastal management in this wider milieu of evolving and multi-layered governance helps to answer the question: why is it so difficult to mobilize effective collective action for coastal sustainability? Understanding and assessing impacts and managing coastal activities are fundamentally complex and preclude a one-size-fits-all governance panacea. Resolving the coastal innovation paradox necessitates integrated, contextually appropriate innovation across governance episodes, processes and cultures - the institutional architecture of governance. Future business and technological innovation needs to be reframed and underpinned by transformational social and governance innovation to secure a sustainable future for the world's coastal communities. The second article [1] outlines a transformative practice of deliberative coastal governance to chart a course towards this end.

\section{The Coastal Innovation Problématique and Innovation Paradox}

We are living in an era characterised by human domination of the Earth-described by Nobel Laureate Paul Crutzen [2] and colleagues [3] as the "Age of the Anthropocene". About 40\% of all the biological production of the planet's land mass, i.e., $40 \%$ of terrestrial net primary productivity is appropriated for human consumption [4]. An estimated $60 \%$ of global ecosystem services are in decline at the very time that consumption of over $80 \%$ of these services has increased [5]. Ecosystem services include life-sustaining regulating services (such as climate, air and water quality regulation), provisioning services (such as food and fibre) and cultural services (such as the religious and spiritual values of nature). We may be transgressing critical planetary boundaries: earth-system processes and thresholds that, if crossed, could imperil human survival and well-being [6]. Environmental management efforts have not adequately addressed the root causes and drivers of human actions that diminish ecosystem services, reduce livelihood sustainability and escalate disaster risk. The rate and scale of human-induced global change may endanger contemporary civilization [7-11]. Consequently, there is a compelling need to understand this predicament and navigate a way out of this sustainability crisis. It is a crisis because the rate and scale of global change is unprecedented in human history. It is a crisis because the nature and consequences of global change are characterized by complexity, uncertainty, ambiguity and surprise and jeopardize both short- and long-term societal aspirations. It is a crisis because the transition to sustainability necessitates a paradigm shift in thinking and practice. The coast is the frontline of this sustainability crisis.

Biologically diverse and productive coasts are the interface between the terrestrial and marine realms. They are the quintessential place of nature's bounty and opportunity. Coastal ecosystems play 
a pivotal role in the healthy functioning of global biogeochemical systems and processes, for example, intercepting, storing and processing much of the terrestrial nitrogen flux [12,13], acting as nurseries for a range of culturally, recreationally and commercially important species and supporting extraordinary biodiversity [14-16]. Martinez et al. [16] estimate that the total value of coastal ecosystem services is $77 \%$ of the total global ecosystem services value of USD 33,268 $\times 10^{9}$ per annum (pa) (i.e., $\$ 33$ trillion pa) - well over twice the total economic (market plus non-market) value of terrestrial ecosystem services - calculated by Costanza et al. [17]. Assigning a dollar value is instructive, but does little to reflect the spiritual and cultural value of coasts [18]. Coasts constitute only a small portion of the planet; about $1.2-12 \%$ of the earth's surface [16,19]. However, they are disproportionately productive and valuable. Consequently, coasts are thus the locus of acute population growth and development intensification. An estimated $41-45 \%$ of global economic activity occurs at the coast, 21 of the world's 33 megacities are coastal and $40-50 \%$ of the human population lives within $100 \mathrm{~km}$ of the sea $[16,19,20]$. Moreover, coastal economic activity and populations are growing faster than those in inland areas. Coasts are thus the primary habitat of humanity.

Human ingenuity and innovation have reaped handsome rewards from the coast. For millennia, innovations in boat design and naval architecture have helped to catalyse and facilitate maritime trade and cross-cultural connections and shaped global geopolitics. Sea-worthy vessels were developed some 45,000 years ago - long before maritime trade facilitated the expansion of the Arab empire in the 7th-13th centuries and later European exploration and colonization of the new world from the 15th century through to more contemporary industrialization and economic globalization [21]. Innovative building and infrastructure designs and construction practices laid the physical foundation and continue to open up opportunities for strategically located coastal cities and towns (viz. modern coastal engineering feats, such as the London's Thames flood barrier, Hong Kong's international airport on reclaimed land or the coastal defences that were developed over centuries to safeguard Holland). Innovation underpins successful port strategies (e.g., initiatives in communications, technology, layout and sustainability at the Port of Rotterdam). More generally, the prosperity of coastal communities has been enabled by innovative governance arrangements at various temporal and geographic scales. The work of Ostrom, e.g., [22,23], in particular has shown that coastal and other communities can develop and sustain innovative and sophisticated decision-making processes and enforcement mechanisms to resolve conflicting interests to manage common property resources on a sustainable basischallenging conventional wisdom that control by central authorities or privatization is necessary to avert the tragedy of the commons. The crafting of the United Nations Convention on the Law of the Sea (UNCLOS) and associated agreements established the internationally recognized innovative regime for governing marine affairs. In short, diverse technological, business and socio-political innovations have enabled humanity to flourish in coastal localities around the globe.

Despite these innovations, coasts are under siege: coastal and marine ecosystems are amongst the most imperilled of the earth's systems [5,24,25]. Coastal-marine ecosystems are deteriorating faster than any other system [25], and the extent of coastal degradation may already exceed that of any terrestrial system [26]. These impacts are driven by a complex synergy of human activities that include habitat transformation and destruction to make way for agriculture, mariculture and urban development; overexploitation of coastal resources, such as fish; the release of a wide array of point and non-point source pollutants; invasive exotic species; and abstraction from and alteration, damming 
and attenuation of river systems that have profound impacts on coastal ecosystems and the sustainability of coastal livelihoods [27]. The synthesis of the first 10 years of research by the Land Ocean Interactions in the Coastal Zone (LOICZ) programme clearly demonstrates that global change jeopardizes the continued healthy functioning of coastal systems and their ability to sustain human development [28]. Moreover, the prognosis for the future is bleak, especially given the anticipated impact of climate change on the coast, which poses a grave threat to inter alia densely populated low-lying deltaic coasts and small island developing states [29].

Hence, the coastal problématique: human ingenuity and innovation have precipitated and are accelerating coastal degradation, escalating disaster risk and endangering coastal livelihoods and, consequently, global human well-being. With the majority of the world's population and economic activity at the coast, the coast is the frontline of the sustainability crisis. How this crisis is handled at the coast, therefore, sets the course for humanity's struggle for sustainability.

The coastal problématique is the archetypal wicked problem, which, as explained by Rittel and Weber [30], cannot be defined unambiguously or readily distinguished from other social dilemmas. Moreover, it defies technical or optimal solutions and is inherently unresolvable in any objective or scientific sense. Global change manifests itself with particularity in different coastal localities and regions, reflecting the complex interplay of distinctive environmental, social, economic and cultural dynamics, prevalent power differentials, injustice and inequity and divergent worldviews about how to reconcile short- and long-term, public and private risk and interests. Business-as-usual is unsustainable and untenable. The coastal problématique is not amenable to technical fixes or blueprint panaceas. Hence, the innovation paradox: innovation is necessary to escape the vulnerability trap that past ingenuity and prevailing endeavours have sprung upon humanity. New forms of innovation are essential to secure the safety and sustainability of coastal communities. Business and technological innovation need to be reframed and underpinned by transformative social and governance innovation to build a prosperous and sustainable future for the world's coastal communities.

\section{The Nature and Dimensions of Innovation}

\subsection{What is Innovation?}

The work of Schumpeter [31] is often cited as the point of departure for the study of innovation. He defined innovation as a process that starts with the germ of an idea and progresses all the way to the development of a marketable product that transforms the economy. Among other things, Schumpeter described innovation as the outcome of entrepreneurs creating novel combinations of product (a new good or service) and process (a new production or organizational process) innovation types. The study of innovation has progressed considerably since then. For example, in addition to private sector product and process innovation types, governance and public sector innovations include service innovation (new ways of providing services, e.g., on-line tax forms), position innovation (new contexts or users, e.g., the services for end-users), strategic innovation (new goals or purposes of the organization, e.g., community policing), governance innovation (new forms of citizen engagement and democratic institutions, e.g., devolved government) and rhetorical innovation (new language and new concepts, e.g., a carbon tax) [32]. 
In practice, innovations may involve elements of several types of innovation, and more complex innovations are likely to be multi-dimensional [32]. Not surprisingly, there are many definitions of the term innovation. Common to most definitions is the implementation of new or unconventional ideas and practices [31-37]. Innovation is more than a minor improvement; it constitutes a transformation in processes, practices organizations and/or systems. A distinction can, however, be made between incremental and radical innovations to distinguish those innovations that represent incremental advances on prevailing practice from those that mark a sea-change. A distinction can also be made regarding the mode of innovation viz. component versus architectural innovation. The former refers to changes in individual components of a system, with the system remaining intact, whereas the latter refers to overhauling the system design and, hence, the way in which the components interact. In sum, innovation is the practical application of novel ideas that results in significant real-world change; thus, distinguishing the concept from invention, creativity and ingenuity. What can be learned from innovation scholarship to chart a new course for coastal sustainability?

\subsection{Innovation in Business, Society, Environment and Governance}

There is a vast scholarship on innovation. It is beyond the scope of this article to review this entire literature. Table 1 provides a sampling of contemporary literature on innovation in technology, business, commerce and industry; and society and the environment.

Table 1. Sampling of business, social and environmental innovation literature.

\begin{tabular}{|c|c|c|}
\hline $\begin{array}{l}\text { Innovation in technology, } \\
\text { business, commerce and industry }\end{array}$ & Social innovation & Environmental innovation \\
\hline $\begin{array}{l}\text { Introduction and overview } \\
\qquad[38,39]\end{array}$ & $\begin{array}{c}\text { Role of social innovation in } \\
\text { fostering community well-being } \\
{[48,49]}\end{array}$ & $\begin{array}{c}\text { Meaning, barriers, policies and } \\
\text { strategies for making the } \\
\text { transition to sustainability } \\
{[56-62]}\end{array}$ \\
\hline $\begin{array}{l}\text { Nature of innovation and } \\
\text { approaches for strategizing } \\
\text { organising and managing } \\
\text { innovation }[37,40]\end{array}$ & $\begin{array}{c}\text { Role of social entrepreneurs in } \\
\text { stimulating social innovation } \\
{[50]}\end{array}$ & $\begin{array}{l}\text { Role of innovation in } \\
\text { sustainable business } \\
\text { development }[63,64]\end{array}$ \\
\hline $\begin{array}{l}\text { Facilitating technological } \\
\text { innovation }[41]\end{array}$ & $\begin{array}{l}\text { Social innovation and citizen } \\
\text { movements [51] }\end{array}$ & $\begin{array}{l}\text { Innovation in environmental } \\
\text { policy-making [65-67], } \\
\text { including the temporal } \\
\text { dimension of policies and } \\
\text { practices [68] }\end{array}$ \\
\hline $\begin{array}{l}\text { What managers can do to } \\
\text { stimulate innovation and } \\
\text { creativity [42] }\end{array}$ & $\begin{array}{l}\text { Methods for experimental social } \\
\text { innovation [52] }\end{array}$ & $\begin{array}{l}\text { Unions, innovation and } \\
\text { sustainable development [69] }\end{array}$ \\
\hline $\begin{array}{c}\text { The role of problem-solving in } \\
\text { sustaining innovation [43] }\end{array}$ & $\begin{array}{c}\text { Cultural expression, creativity } \\
\text { and innovation [53] }\end{array}$ & $\begin{array}{c}\text { Indicator systems for } \\
\text { sustainability innovation [70] }\end{array}$ \\
\hline
\end{tabular}


Table 1. Cont.

\begin{tabular}{|c|c|c|}
\hline $\begin{array}{l}\text { Innovation in technology, } \\
\text { business, commerce and } \\
\text { industry }\end{array}$ & Social innovation & Environmental innovation \\
\hline $\begin{array}{l}\text { Knowledge management in an } \\
\text { age of complexity [44] }\end{array}$ & $\begin{array}{l}\text { Innovation and disaster resilient } \\
\text { communities [54] }\end{array}$ & $\begin{array}{l}\text { Innovation trends in and } \\
\text { opportunities for sustainability } \\
\text { in learning societies [71] }\end{array}$ \\
\hline $\begin{array}{l}\text { Innovation and entrepreneurship } \\
\qquad[45]\end{array}$ & $\begin{array}{l}\text { Social innovation at different } \\
\text { points in history [55] }\end{array}$ & $\begin{array}{l}\text { Environmental innovation that } \\
\text { is issue-specific, e.g., global } \\
\text { warming and social innovation } \\
\text { [72]; discipline-specific, e.g., } \\
\text { coastal engineering [73]; } \\
\text { locality-specific, e.g., } \\
\text { innovative states [58] and } \\
\text { regions [74,75]; community } \\
\text { focused [76]; and sector- } \\
\text { specific, e.g., sustainable energy } \\
\text { [77] and electricity systems [78] }\end{array}$ \\
\hline \multicolumn{3}{|l|}{$\begin{array}{l}\text { Tools for creative thinking and } \\
\text { innovation [46] }\end{array}$} \\
\hline \multicolumn{3}{|l|}{ Design-driven innovation [47] } \\
\hline
\end{tabular}

Much of the literature on innovation is framed by the imperative to foster innovation in technology and business, with a focus on the private sector and at the organizational level of analysis. This focus is obviously too narrow for understanding how to transform unsustainable coastal livelihoods. Consideration needs to be given to innovations in societal practices, processes, institutions, structures and systems, i.e., social innovation, and to insights from the growing literature on environmental innovation [79], also referred to as green capitalism [80,81], green technology [82] and sustainability- [83,84] or eco-innovation. Broadly speaking, eco-innovation is the process of developing new ideas, products and processes and adjusting behaviour to achieve ecologically sustainable outcomes. This scholarship recognizes that sustainable business and technological innovations are facilitated by enabling social institutions and calls for complementary or co-evolutionary innovation across business, technological and socio-political domains.

There is also an emerging literature on public sector and governance innovation [32,36,85-93] that has particular relevance to coastal management thinking and practice. Governance innovations include, for example, institutional changes (e.g., devolution of functions from higher to lower spheres of government), changes in how services are provided (e.g., privatization of formerly State owned entities) and new cooperative arrangements to make public decisions, provide public services or administer public assets (e.g., various consultative, cooperative or collaborative arrangements in which government shares some level of responsibility with other actors from the private sector and civil society). Navigating the transition to coastal sustainability clearly necessitates innovation in the governance arena. What then are the distinguishing features of governance innovation? 


\subsection{Distinguishing Features of Governance Innovation}

Innovation in the private and public sectors differs significantly. Lessons cannot be transferred simplistically from the former to the latter [32,92]. Governance innovations differ from intra-organizational innovations in products, services and production processes in at least two respects: they are supra-organizational, involving networks of actors in transforming social systems; and they extend beyond the development of products and productive processes to include the ways in which productive activities are resourced, the processes to decide what to produce and the normative standards used to assess the performance of the social production system [92]. According to Hartley [32], innovation in the private sector is a virtue in itself, enabling companies to secure a competitive edge. In the public sector, however, increasing public benefits and value (e.g., improved service quality through agency re-organization) is necessary to justify innovation. Therefore, in the public sector context, a distinction needs to be made between innovation and improvement. There is value in learning from innovation successes and failures, because this can shed light on barriers and opportunities for public sector innovation. This is particularly relevant for consideration of how systems approach frameworks and how similar modes of innovation can be incorporated into public sector practice. Innovation in the public sector is best viewed as a journey, rather than as a linear process. Moreover, compared to the tangible reality of business and technological innovation, public sector and governance innovations tend to be more intangible and ambiguous, because they typically lead to new public services, changed relationships and political processes, rather than products and production processes. Arguably, the most critical factor shaping the success of innovation in the public sector is effective relationships and linkages between the innovators and end-users and key elements in the social production supply chain [90].

The diffusion of innovations from early adopters to others or from one organization, locality, jurisdiction or era to another has particular significance in the public sector [94]. Whereas competitive advantage tends to inhibit innovation sharing between firms, improving governance performance stimulates sharing or transfer of best practices to increase public value and benefits. According to Rogers [95], innovations are not adopted on the basis of rational reflection on compelling scientific evidence. Rather, people adopt innovations on the basis of subjective values and societal norms mediated through interpersonal networks. Innovations are often initially perceived as uncertain and even risky, and therefore, people seek out others like them who have already adopted new ideas. Early adopters share their experience with their network of acquaintances; a process that can take a long time. Those who shape public opinion and who draw on networks within and beyond a community can act as brokers for the diffusion of innovation. The rapid spread of the Internet in the 1990s is a defining exception regarding the speed of adoption. The Internet has transformed communication and social networking and, consequently, how people adopt new ideas. In general, the rate of innovation diffusion is closely related to the innovation's relative advantage, compatibility, trialability and observability, but, inversely, proportional to its complexity [95]. Diffusion of innovation across the public sector may be slower and more difficult than that in the private sector, and the transformation of public services and systems can take longer than that in the private sector [90]. Professionals and public sector administrators can play a key role in both the development and diffusion of innovation. Local adoption typically requires adaptation to local circumstances. Much remains to be done to understand the 
opportunities and barriers to the diffusion of governance innovations. In particular, there is a need to understand better how networks hinder or facilitate public sector innovation through top-down, bottom-up and/or lateral processes of decision-making and practice; and the direct and indirect influences of the societal setting.

Moore and Hartley [92] identify five inter-related characteristics that distinguish public sector innovations in governance from innovation in the private sector. First, innovations in governance extend beyond specific organizational boundaries to encompass the networked decision-making, financing and production systems of the entire social production process that potentially affects all citizens. Such innovations reshape where and how socially productive activity occurs. In the past, public service was the domain of governments, but it has been redefined so that responsibilities now extend to a wide range of governance actors. This systemic change reconfigures the discourses, arenas, networks and production systems for making social choices. Second, governance innovations tap into new resources, including financial resources, labour and materials, as well as specialized operational capabilities to achieve specific outcomes not previously accessible to the public sector. Third, governance innovations extend the range of instruments available to governments to achieve societal goals. Traditional police powers, taxation authority and the democratic mandate are supplemented by moral persuasion to engage other role-players in public service. These changes are more than superficial in that they can (re)shape the rules of the game, such as property rights and governance roles and responsibilities. Fourth, governance innovations redistribute the right to decide on the use of public assets and to define and judge public value. More actors are involved in the governance process and reframe choices about what ought to be done, by whom, for whom, how, etc. In some cases, government has opened up decision rights to other actors in civil society and the private sector. In other cases, the decision-making locus has shifted from the individual to the state. Finally, governance innovations need to be evaluated by the extent to which they enhance public value or improve social performance - and, in particular, the extent to which they advance societal goals. In contrast, private sector innovations can be evaluated by instrumental or utilitarian measures, such as lower production costs. Efficiency and effectiveness may suffice as innovation measures for private sector organizations. However, public sector innovations in governance use government authority and resources and redefine rights and responsibilities for determining outcomes valued by the public. Governance innovation should therefore be judged in terms of equity (i.e., fairness and justice) and sustainability, as well as efficiency and effectiveness in achieving societal goals.

There has been a revolution in the governance of social production systems as many governments explore new ways to resource their activities and build operational capacity and overall legitimacy to achieve their objectives. These innovations have been systemic and diverse and underpin the transition from traditional hierarchical government decision-making towards networked governance and more devolved, horizontal, hybridized, communicative and associational forms of governance [96-103]. Understanding this evolution in governance and corresponding innovation characteristics helps to locate coastal management endeavours, sheds light on why the coastal problématique persists despite coastal management being an innovative arena of environmental governance and suggests opportunities and challenges for future innovation. 


\section{Evolving Governance, Innovation and Coastal Management}

\subsection{The Changing Character of Governance and Innovation}

The term government refers to the formal organization of the public sector or state. Governance is more than government and refers to the interactions of actors from the state, civil society and the private sector to solve societal problems through power sharing, social coordination and collective action [104]. Governance institutions extend beyond organizational structures and rules to include the societal norms and standards that shape public values and perceptions and the interactions that take place through formal and informal social choice mechanisms. Therefore, to understand governance, one needs to focus on relevant actors, interactive practices, arenas and networks. One also needs to understand how governance discourses and practices evolve and the inter-relationships between specific governance episodes and underlying cultural norms and values and the interconnections between the activities of particular actors, their networks and arenas of interaction, as well as wider and deeper structuring forces [105]. Governance institutions typically have two countervailing features. On the one hand, they are authoritative, constraining, disciplining and stabilizing. On the other hand, they are generative, enabling, empowering and innovative. The challenge is to engage these dynamic countervailing features in appropriate circumstances to foster individual behaviours and citizen interrelationships that are socially equitable and desirable [105].

Ideological conceptions and practices of governance and public sector management have evolved significantly in the post-war period, with significant corresponding innovations and improvements $[32,92,105]$. For much of this time, governance was characterized as public service by governments based on well-established administrative routines and rule-bound procedures that were seen by many as the antithesis of creativity and innovation. Yet, in recent decades, in the face of complex evolving and interconnected societal concerns, governance has opened up to include new working relationships between the state and key actors in civil society and the private sector. Three broad themes of governance and public management can be distinguished and reflect different ways in which innovation is generated and adopted (see Table 2). This portrayal of evolving governance genres and associated innovation draws mainly on Hartley [32], as well as selected literature on governance and global change [106,107]. These conceptualizations of governance reflect distinctive ideologies and can be associated with particular time periods. However, in practice, these alternative framings of governance overlap and even co-exist. They also compete, because they reflect divergent ideologies and posit alternative roles and responsibilities for policy-makers, public managers and the public. The three conceptions of governance, and corresponding innovation characteristics, are traditional public administration, New Public Management and networked governance. 
Table 2. Conceptions of governance and corresponding innovation (After Hartley [32]; Chapin et al., [106]; Underdal [107]).

\begin{tabular}{|c|c|c|c|}
\hline & $\begin{array}{l}\text { Traditional public } \\
\text { administration }\end{array}$ & New Public Management & Networked governance \\
\hline Context & Homogeneous and stable & $\begin{array}{c}\text { Competitive, } \\
\text { self-interested individuals }\end{array}$ & Diverse and in flux \\
\hline $\begin{array}{c}\text { Needs/ } \\
\text { problems }\end{array}$ & $\begin{array}{l}\text { Complicated; defined } \\
\text { by professionals }\end{array}$ & $\begin{array}{l}\text { Wants expressed } \\
\text { through markets }\end{array}$ & $\begin{array}{l}\text { Complex, volatile and } \\
\text { prone to risk }\end{array}$ \\
\hline $\begin{array}{l}\text { Modalities of } \\
\text { governance }\end{array}$ & $\begin{array}{l}\text { Hierarchies; } \\
\text { public servants }\end{array}$ & $\begin{array}{l}\text { Markets; purchasers and } \\
\text { providers; clients } \\
\text { and contractors }\end{array}$ & $\begin{array}{l}\text { Networks and } \\
\text { partnerships; } \\
\text { civic leadership }\end{array}$ \\
\hline Strategy & $\begin{array}{c}\text { State- and } \\
\text { producer-oriented }\end{array}$ & $\begin{array}{c}\text { Market- and } \\
\text { consumer-oriented }\end{array}$ & Shaped by civil society \\
\hline Key concepts & Public goods & Public choice & Public value \\
\hline Key goals & Maintain stability & Efficient service delivery & $\begin{array}{l}\text { Resilient and sustainable } \\
\text { socio-ecological system }\end{array}$ \\
\hline Uncertainty & $\begin{array}{l}\text { Reduce uncertainty, then } \\
\text { take action }\end{array}$ & $\begin{array}{c}\text { Discount future and rely } \\
\text { on market forces to guide } \\
\text { service provision }\end{array}$ & $\begin{array}{l}\text { Embrace uncertainty: } \\
\text { retain flexibility to adapt }\end{array}$ \\
\hline Innovation & $\begin{array}{l}\text { Some large-scale national } \\
\text { and universal innovations }\end{array}$ & $\begin{array}{c}\text { Innovations in } \\
\text { organisational form more } \\
\text { than content }\end{array}$ & Innovation at all levels \\
\hline Improvement & $\begin{array}{l}\text { Large step-change } \\
\text { improvements initially, } \\
\text { but less capability for } \\
\text { continuous improvement }\end{array}$ & $\begin{array}{c}\text { Improvements in } \\
\text { managerial processes and } \\
\text { systems; customer focus } \\
\text { produces quality } \\
\text { improvements in } \\
\text { some services }\end{array}$ & $\begin{array}{c}\text { Aiming for both } \\
\text { transformational and } \\
\text { continuous improvement } \\
\text { in front-line services }\end{array}$ \\
\hline $\begin{array}{c}\text { Role of } \\
\text { policy-makers }\end{array}$ & Commanders & $\begin{array}{l}\text { Announcers/ } \\
\text { commissioners }\end{array}$ & Leaders and interpreters \\
\hline $\begin{array}{l}\text { Role of public } \\
\text { managers }\end{array}$ & Clerks and martyrs & $\begin{array}{c}\text { Efficiency and } \\
\text { market maximisers }\end{array}$ & Explorers \\
\hline $\begin{array}{l}\text { Role of the } \\
\text { public }\end{array}$ & Clients & Customers & Co-producers \\
\hline
\end{tabular}

These portrayals of governance reflect divergent conceptualizations of the context and nature of societal needs and problems. They also indicate starkly different governance modalities, strategies and key concepts and goals. From the Second World War through to the 1980s, traditional public administration delivered public services through top-down legislation and rule-based bureaucracies. The governance context was typically portrayed as homogeneous, and needs and problems were considered to be complicated, but defined, analysed and solvable by professionals using technical analysis to achieve the public good and maintain stability in the face of an uncertain future. National and even universal innovation was brought about, but implementation was typically top-down - with associated prescribed roles for policy-makers, public managers and the public — and limited capacity 
for ongoing improvement and adaptation. The introduction of New Public Management from the early 1980s constituted a radical departure - supplanting big government with governance ostensibly through the free market. Underpinned by neo-liberal thinking and a concomitant focus on cost-effective, efficient and customer-oriented provision of public services, these sweeping innovations resulted in extensive restructuring of government agencies and privatization of a range of public services. However, the extent to which these innovations have brought about societal improvements is deeply contested. As explained at the start of this article, these two conceptualizations of governance have done little, at best, to avert the unfolding sustainability crisis. These conceptions of governance stand in stark contrast to the emerging genre labelled networked governance. In contrast to the false dichotomy between big government and the free market, networked governance seeks to mobilize collective action through diverse governance modalities underpinned by collaborative partnerships and civic leadership. Innovation needs to take place across all levels of governance, and the roles of policy-makers, public managers and the public is appropriately and fundamentally redefined. However, there are inevitably tensions between centralization and decentralization and networks and hierarchies. Moreover, governance is imbued with milieu-specific cultures and practices that are located in and are reshaping and being reshaped by particular cultural, economic, social and political dynamics. These genres of governance, thus, co-exist and co-evolve with context-specific dynamics, giving rise to distinctive discourses and practices. However, despite wholesale governance innovations since the middle of the last century, the sustainability crisis is pervasive and deepening, especially at the frontline of the coast. How does coastal management fit into this wider governance setting; and how can coastal management endeavours be mobilized to facilitate the transition to coastal sustainability? In short, how can the coastal innovation paradox be addressed?

\subsection{Coastal Management in the Context of Governance Innovations}

Coastal management has been in the vanguard of innovative environmental governance efforts that have experimented with hybrid strategies involving diverse actors in pursuit of sustainability in a range of settings [108,110]. However, the coastal problématique persists. Why this impasse? More specifically, why is it so difficult to mobilize effective collective action for coastal sustainability? Figures 1 and 2 adapt work by Healey and others [91,105,111,112] to portray the multi-layered character of governance and how collective action is mobilized within and between different levels. These layers are ever-present and constantly interacting, though the dynamics of different levels operate at different speeds and scales and through different configurations of driving dynamics (see Figure 1).

Specific governance episodes are the visible reality of particular actions and encounters. For example, a partnership between local residents, a conservation non-governmental organization and the local authority might secure resources to undertake a dune restoration project to manage coastal erosion. The governance processes that set the rules of the game are where strategic direction and projects for governance are created, framed and managed. This is where power dynamics are constructed through coalition building and power politics; where power struggles ensue over who frames and determines meaning, ideologies, practices and resources. For example, in the face of coastal erosion and notwithstanding episodes, such as a local dune restoration project, politically and 
economically powerful beachfront property owners might be able to use their elite networks to mobilize political will and government resources to construct a publicly subsidized hard-engineered seawall to protect their properties against the threat posed by an imminent coastal storm season. Such actions perpetuate prevailing political and economic interests and might result in environmental impacts and outcomes that are the antithesis of the dune restoration endeavour and wider societal interests. Governance processes (level 2) are connected to and constrained by specific episodes (level 1) and the interests and capacities of relevant actors; and by the governance cultures (level 3) that may or may not legitimize what individual actors do and how governance processes unfold in particular contexts. Governance cultures may help or hinder the capacity of those seeking to make particular strategic moves; or dynamics may evolve that challenge or reinforce the power of strategic actors. Continual interaction between these layers of governance ensures that each level is influenced by the dynamics and driving forces welling up from below or filtering down from above. A variety of studies demonstrate that social and governance innovation at the grassroots level can only become transformative if it helps to overcome the authoritarianism that is characteristic of many capitalist societies [113-115]. Swyngedouw [116] argues that socially innovative approaches to governance-beyond-the-state are decidedly Janus-faced (i.e., two-faced), particularly under circumstances where politics-as-usual is dominated by market interests that erode democracy. Some assert that innovative forms of participatory governance have become a new form of tyranny [117-118]. Prevailing governance innovation is characterized by ambiguity at best and dissonance at worstthwarting collective action for sustainability (see Figure 2).

Figure 1. Layers of governance episodes, processes and cultures.

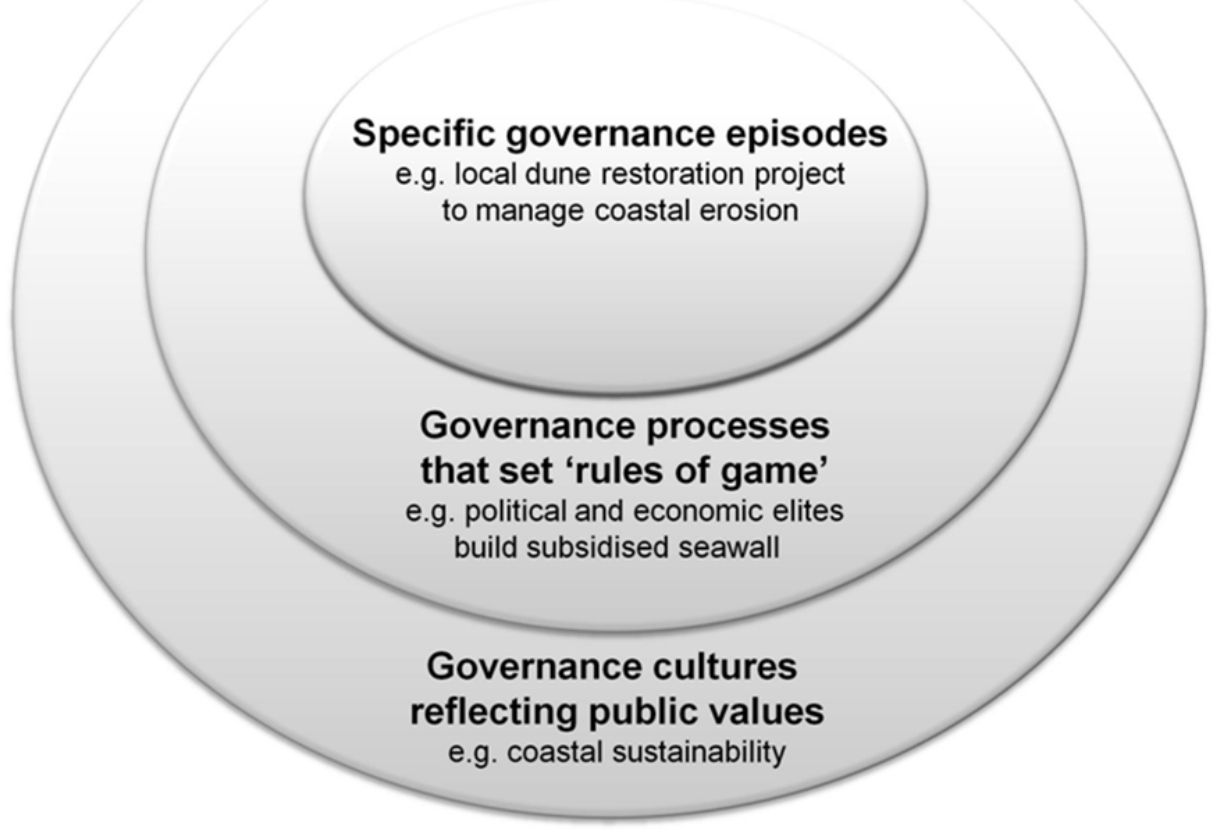


Figure 2. From dissonance to coherent governance episodes, processes and cultures.

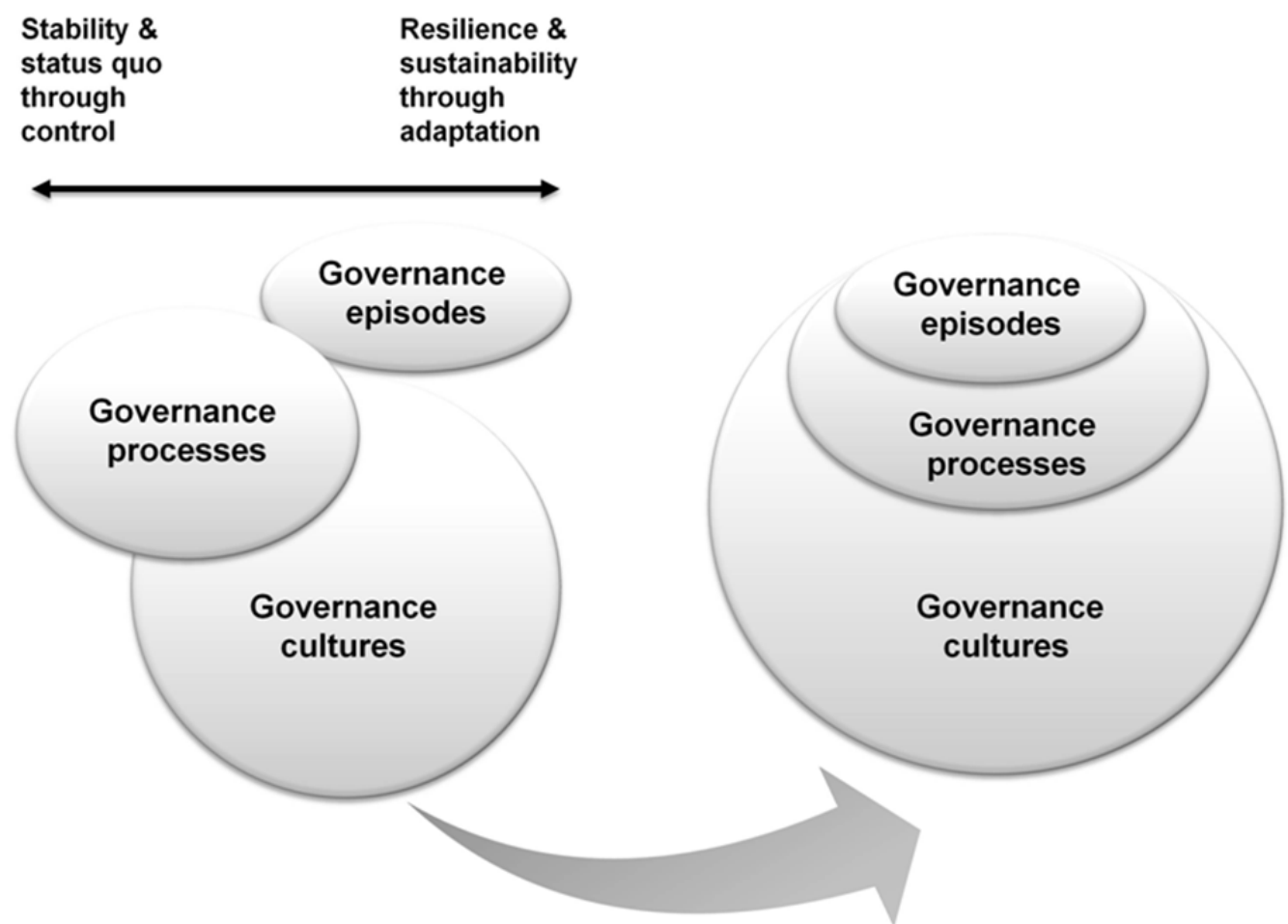

Work by Healey and colleagues demonstrates that governance processes (level 2) have typically been a significant obstacle to the diffusion of social learning from specific episodes (level 1) and to the realization of a governance culture (level 3) commensurate with societal aspirations for increased engagement, relevance and legitimacy. Like the urban settings that Healey's work explores, the coastal setting is characterized by complex dynamics between and within these interacting governance layers. For example, particular coastal management episodes are shaped by internal dynamics, as well as external actor interests and interactions through the discourses, networks and resources that frame the governance processes and define the rules of the game and through the more diffuse political, economic and socio-cultural processes that frame governance cultures. Governance episodes, such as a local dune restoration project, that strive to transform unsustainable practices may introduce innovative ways of thinking and working that are exquisitely responsive to local needs. However, such efforts are easily thwarted if dominant governance processes pursue goals that are unsustainable and mobilize controlling processes and practices to maintain the status quo, as suggested by the example of local elites mobilizing public resources to build a seawall to reduce their exposure to hazard risk. However, there is not necessarily a predetermined functional fit between wider governance processes and cultures and a particular governance episode, because local history, circumstance, capacity, opportunity and creativity can reshape future governance directions.

"External pressures may push in similar directions, but will always become concrete only in relation to specific local conditions, linked to local histories, capacities and opportunities. Structural power may widen cracks in existing institutional landscapes through which new ideas, new actors, new arenas and networks and new practices may push through to expand and flow around a governance landscape. But whether these 
openings are exploited, by whom and for whom will always remain contingent on local conditions, including the availability of what may be called 'imaginative strategic grasp', a kind of intellectual/practical creative energy. Thus the trajectories of urban [or coastal] governance transformation are not just contingent on the local institutional landscape but, but are shaped by the imaginations which frame the mobilisations and struggles of transformation processes" [105].

There is a deep-rooted cultural shift in perceptions about how coastal governance should work. Many coastal communities are engaging in enterprising episodes of collective action to change how governance works, creating a squeeze on dominant governance processes, discourses and practices. Transformative social innovation in governance at a local level will only occur when formerly excluded social groups are integrated into dominant processes [113-116,119]. This insight is consistent with environmental governance scholarship that demonstrates that there is no fixed spatial or temporal level appropriate for governing ecosystems. Rather, governance institutions need to recognize the multi-level character of environmental problems and build social capital and stimulate innovation and social learning within and between governance levels [22,23,106,108,110,120-123]. Therefore, to chart a new course towards coastal sustainability, it is necessary for coherent innovations to take place at all levels of governance. Prevailing dissonance is inimical to transformative innovation. There is a need for coherent innovation in governance episodes, processes and culturesthe institutional architecture of governance-to facilitate the transition towards sustainability (see Table 3).

Table 3. Layers of governance and dimensions of innovation (After Healey [105]).

\begin{tabular}{lll}
\hline Layers of governance & Dimensions of innovation \\
\hline Specific governance & - & Diverse actors \\
episodes & - & Open, accessible and safe arenas \\
& - & Ambiences are welcoming, respectful, knowledgeable and \\
& & stimulating; with generative and insurgent potential \\
\hline $\begin{array}{l}\text { Governance processes } \\
\text { that set rules of }\end{array}$ & - & Networks and coalitions are diverse and mutually aware, \\
the game & loosely-coupled and flexible \\
& - & Stakeholder selection processes are open, transparent, safe \\
& and flexible \\
& - & Open-minded, inclusive, informative and inventive discourses \\
& Facilitative and experimental practices, supporting \\
& - & Laws, formal competences and resource flow principles value \\
& local initiative and encourage experimentation \\
\hline Governance cultures & - & Diversity is valued; attention focused on real-world societal \\
& concerns; emphasis on performance not conformance \\
& - & Identity and open negotiation of values and ethics beyond \\
& utilitarianism and consumerism; open-minded tolerance and \\
& sensitivity encouraged \\
& - & Self-regulative and distributive; supportive and constraining \\
\hline
\end{tabular}


Coherent governance innovation involves governance episodes that engage diverse actors in a range of open arenas that create safe, but stimulating, settings for developing new patterns of sustainability thinking and practice. Governance processes need to be similarly inclusive, open and safe; and stimulate and sustain inventive discourses, processes and practices through enabling formal and informal institutions. Supportive governance cultures recognize and value diversity, facilitate reflection on societal norms and values and encourage dialogue, experimentation and deliberation. This is a tall order. Systemic governance innovations in recent decades have done little to avert the sustainability crisis and, arguably, may have precipitated the crisis. Paradoxically, innovation is necessary to navigate a way out of the vulnerability trap that past innovation has unwittingly set. Business-as-usual needs to be transmogrified. Hence, the coastal innovation imperative: business and technological innovation needs to be reframed and underpinned by transformative social and governance innovations that secure a sustainable future for the world's coastal communities. Coherent innovations in governance episodes, processes and cultures are necessary to chart this new course.

\section{Conclusions}

Human ingenuity and innovation have precipitated a sustainability crisis. Coasts are the primary habitat of humanity and the frontline in this crisis. How this crisis is addressed at the coast will set the course for humanity's struggle for sustainability. Paradoxically, innovation is necessary to navigate a way out of the vulnerability trap set by past innovations. New forms of innovation are needed to secure the safety and sustainability of coastal communities and, consequently, human well-being. Innovation scholarship demonstrates that private sector innovations differ markedly from those in the public sector and governance more generally. Notwithstanding wholesale governance innovations in recent decades, the sustainability crisis persists. The shift from traditional public administration and New Public Management towards networked governance opens up intriguing possibilities for coastal sustainability. However, dominant governance processes that set the rules of the game tend to reinforce the status quo. Innovative governance episodes that might open up opportunities for responsive and adaptive practices and governance cultures conducive to sustainability are crowded out. Transformative innovation necessitates governance episodes that engage diverse actors in a range of open arenas that create safe, but stimulating, settings for eliciting new patterns of sustainability thinking and practice. Governance processes need to be empowering; providing an inclusive and secure setting that stimulates inventive discourses, processes and practices. Supportive governance cultures recognize and value diversity, facilitate reflection on societal norms and values and encourage dialogue, experimentation and deliberation. Hence, the coastal innovation imperative: to reframe and underpin business and technological innovation with coherent governance innovations that lead to social transformation for sustainability. The following article builds upon conclusions drawn here and posits a transformative foundation of deliberative coastal governance to stimulate innovation and facilitate the transition to coastal sustainability. 


\section{Acknowledgments}

The financial support of the New Zealand Earthquake Commission is gratefully acknowledged, but this research is independent of that agency. I appreciate Paul Schneider's assistance in preparing the figures. Constructive reviewer suggestions are gratefully acknowledged.

\section{Conflict of Interest}

The author declares no conflict of interest.

\section{References}

1. Glavovic, B.C. The coastal innovation imperative. Sustainability 2013, submitted for publication.

2. Crutzen, P.J. Geology of Mankind. Nature 2002, 415, 23.

3. Crutzen, P.J.; Stoermer, E.F. The Anthropocene. Global Change Newsletter 2000, 41, 17-18.

4. Vitousek, P.M.; Ehrlich, P.R.; Ehrlich, A.H.; Matson, P.A. Human Appropriation of the Products of Photosynthesis. BioScience 1986, 36, 368-373.

5. Millennium Ecosystem Assessment. Ecosystems and Human Well-being: Synthesis; Island Press: Washington, DC, USA, 2005.

6. Rockstrom, J.; Steffen, W.; Noone, K.; Persson, A.; Chapin, F.S.; Lambin, E.F.; Lenton, T.M.; Scheffer, M.; Folke, C.; Schellnhuber, H.J.; et al. A Safe Operating Space for Humanity. Nature 2009, 461, 472-475.

7. Tainter, J.A. The Collapse of Complex Societies; Cambridge University Press: Cambridge, UK, 1990.

8. Tainter, J.A. Archaeology of Overshoot and Collapse. Annu. Rev. Anthropol. 2006, 35, 59-74.

9. Diamond, J.M. Collapse: How Societies Choose to Fail or Succeed; Penguin: New York, NY, USA, 2006.

10. Homer-Dixon, T.F. The Upside of Down: Catastrophe, Creativity and the Renewal of Civilisation; Island Press: Washington, DC, USA, 2006.

11. McAnany, P.; Yoffee, N.; Questioning Collapse: Human Resilience, Ecological Vulnerability and the Aftermath of Empire; Cambridge University Press: Cambridge, UK, 2009.

12. Howarth, R.; Swaney, D.; Boyer, E.; Marino, R.; Jaworski, N.; Goodale, C. The Influence of Climate on Average Nitrogen Export from Large Watersheds in the Northeastern United States. Biogeochemistry 2006, 79, 163-186.

13. Chen, N.; Hong, H.; Zhang, L.; Cao, W. Nitrogen Sources and Exports in an Agricultural Watershed in Southeast China. Biogeochemistry 2008, 87, 169-179.

14. Carpenter, K.E.; Springer, V.G. The Center of the Centre of Marine Shore Fish Biodiversity: The Philippine Islands. Environ. Biol. Fish. 2005, 72,467-480.

15. Allen, G.R. Conservation hotspots of biodiversity and endemism for Indo-Pacific coral reef fishes. Aquat. Conserv. 2008, 18, 541-556.

16. Martínez, M.L.; Intralawan, A.; Vázquez, G.; Pérez-Maqueo, O.; Sutton, P.; Landgrave, R. The Coasts of Our World: Ecological, Economic and Social Importance. Ecol. Econ. 2007, 63, 254-272. 
17. Costanza, R.; d'Arge, R.; De Groot, R.; Farber, S.; Grasso, M.; Hannon, B.; Limburg, K.; Naeem, S.; O’Neil, R.V.; Paruelo, J.; et al. The value of the world's ecosystem services and natural capital. Nature 1997, 387, 253-260.

18. Sunde, C. The Open Horizon: Exploring Spiritual and Cultural Values of the Oceans and Coasts. In Ecological Economics of the Oceans and Coasts; Patterson, M., Glavovic, B., Eds.; Edward Elgar: Cheltenham, UK, 2008; pp. 166-183.

19. Hinrichsen, D. Coastal Waters of the World: Trends, Threats, and Strategies; Island Press: Washington, DC, USA, 1999.

20. Patterson, M. Ecological Shadow Prices and Contributory Value: A Biophysical Approach to Valuing Marine Ecosystems. In Ecological Economics of the Oceans and Coasts; Patterson, M., Glavovic, B., Eds.; Edward Elgar: Cheltenham, UK, 2008; pp. 140-165.

21. Curtin, P.D. Cross-cultural Trade in World History; Cambridge University Press: Cambridge, UK, 1984.

22. Ostrom, E. Governing the Commons: The Evolution of Institutions for Collective Action; Cambridge University Press: Cambridge, UK, 1990.

23. Ostrom, E. Beyond Markets and States: Polycentric Governance of Complex Economic Systems. Am. Econ. Rev. 2010, 100, 641-672.

24. Nellemann, C., Corcoran, E., Eds.; Our Precious Coasts: Marine Pollution, Climate Change and the Resilience of Coastal Ecosystems; UNEP: Arendal, Norway, 2006.

25. Brown, C., Corcoran, E., Hekerenrath, P., Thonell, J., Eds.; Marine and Coastal Ecosystems and Human Wellbeing: A Synthesis Report Based on the Findings of the Millennium Ecosystem Assessment; UNEP: New York, NY, USA, 2007.

26. Nellemann, C., Hain, S., Alder, J., Eds.; Dead Water: Merging of Climate Change with Pollution, Over-Harvest, and Infestations in the World's Fishing Grounds; UNEP: Arendal, Norway, 2008.

27. Patterson, M.; Hardy, D. Economic drivers of change and their oceanic-coastal ecological impacts. In Ecological Economics of the Oceans and Coasts; Patterson, M., Glavovic, B., Eds.; Edward Elgar: Cheltenham, UK, 2008; pp. 187-215.

28. Crossland, C.J.; Kremer, H.H.; Lindeboom, H.J.; Marshall, C.J.I.; Le Tissier, M.D.A. Coastal Fluxes in the Anthropocene: The Land-Oceans Interactions in the Coastal Zone. In Project of the International Geosphere-Biosphere Programme; Springer: Berlin, Germany, 2005.

29. IPCC. Climate Change: Impacts, Adaptation and Vulnerability; Cambridge University Press: Cambridge, UK, 2007.

30. Rittel, H.W.J.; Weber, M.M. Dilemmas in a General Theory of Planning. Policy Sciences 1973, 4, 155-169.

31. Schumpeter, J.A. The Theory of Economic Development; Harvard University Press: Cambridge, MA, USA, 1934.

32. Hartley, J. Innovations in Governance and Public Services: Past and Present. Public Money and Management 2005, 25, 27-34.

33. Van de Ven, A. Central Problems in the Management of Innovation. Manage. Sci. 1986, 32, 590-607. 
34. Wolfe, R. Organizational Innovation: Review, Critique and Suggested Research Directions. J. Manag. Stud. 1994, 31, 405-431.

35. Utterback, J.M. Mastering the Dynamics of Innovation; Harvard Business School Press: Boston, MA, USA, 1996.

36. Altschuler, A.A., Behn, R.D., Eds.; Innovations in American Government: Challenges, Opportunities and Dilemmas; Brookings Institute: Washington, DC, USA, 1997.

37. Tidd, J.; Bessant, J. Managing Innovation: Integrating Technological, Market and Organizational Change; Wiley: Chichester, UK, 2009.

38. Abramson, M., Littman, I., Eds.; Innovation. Rowman and Littlefield: Lanham, MA, USA, 2002.

39. Dodgson, M.; Gann, D. Innovation: A Very Short Introduction; Oxford University Press: Oxford, UK, 2010.

40. Conway, S.; Steward, F. Managing and Shaping Innovation; Oxford University Press: Oxford, UK, 2009.

41. Dodgson, M.; Gann, D.; Salter, A. The Management of Technological Innovation: Strategy and Practice; Oxford University Press: Oxford, UK, 2008.

42. Prather, C.W. Manager's Guide to Fostering Innovation and Creativity in Teams; McGraw-Hill: New York, NY, USA, 2010.

43. Armstrong, S.C. Sustaining Continuous Innovation through Problem Solving; Industrial Press: New York, NY, USA, 2008.

44. McElroy, M.W. The New Knowledge Management: Complexity, Learning, and Sustainable Innovation; Butterworth-Heinemann: Amsterdam, The Netherlands, 2003.

45. Drucker, P. Innovation and Entrepreneurship; Harper \& Row: London, UK, 2007.

46. Markman, A.B., Wood, K.L., Eds.; Tools for Innovation; Oxford University Press: Oxford, UK, 2009.

47. Verganti, R. Design-driven Innovation: Changing the Rules of Competition by Radically Innovating What Things Mean; Harvard Business Press: Boston, MA, USA, 2009.

48. Agnew, J.A.; Brown, L.A.; Herr, J.P. The Community Innovation Process: A Conceptualisation and Empirical Analysis. Urban Affairs Review 1978, 14, 3-30.

49. Goldsmith, S.; Georges, G.; Burke, T.G. The Power of Social Innovation: How Civic Entrepreneurs Ignite Community Networks for Good; Jossey-Bass: San Francisco, CA, USA, 2010.

50. Perrini, F. The New Social Entrepreneurship: What Awaits Social Entrepreneurial Ventures? Edward Elgar: Cheltenham, UK, 2006.

51. Henderson, H. Social Innovation and Citizen Movements. Futures 1993, 25, 322-338.

52. Fairweather, G.W. Methods for Experimental Social Innovation; Wiley: New York, NY, USA, 1967.

53. Anheier, H., Isar, Y.R., Eds.; Cultural Expression, Creativity and Innovation; Sage: London, UK, 2010.

54. Kendra, J.M.; Watchendorf, T. Community innovation and disasters. In Handbook of Disaster Research; Rodriguez, J., Quarantelli, E.L., Dynes, R.R., Eds.; Springer: New York, NY, USA, 2006; pp. 316-334.

55. Curtis, H., Sanderson, M., Eds.; The Unsung Sixties: Memoirs of Social Innovation; Whiting and Birch: London, UK, 2004. 
56. Rennings, K. Redefining Innovation-Eco-innovation Research and the Contribution from Ecological Economics. Ecol. Econ. 2000, 32, 319-332.

57. Elzen, B.; Geels, F.W.; Green, K. System Innovation and the Transition to Sustainability: Theory, Evidence and Policy; Edward Elgar: Cheltenham, UK, 2004.

58. Falk, J.; Ryan, C. Inventing a Sustainable Future: Australia and the Challenge of Eco-innovation. Futures 2007, 39, 215-229.

59. Hellström, T. Dimensions of Environmentally Sustainable Innovation: The Structure of Eco-innovation Concepts. Sustain. Dev. 2007, 15, 148-159.

60. Mulder, K.F. Innovation for Sustainable Development: From Environmental Design to Transition Management. Sustain. Sci. 2007, 2, 253-263.

61. Carrillo-Hermosilla, J.; del Río Gonźalvez, P.; Könnöla, T. Eco-innovation: When Sustainability and Competitiveness Shake Hands; Palgrave Macmillan: New York, NY, USA, 2009.

62. Smith, A.; Voß, J.-P.; Grin, J. Innovation Studies and Sustainability Transitions: The Allure of the Multi-level Perspective and its Challenges. Research Policy 2010, 39, 435-448.

63. Rainey, D.L. Sustainable Business Development: Inventing the Future through Strategy, Innovation and Leadership; Cambridge University Press: Cambridge, UK, 2006.

64. Wüstenhagen, R., Hamschmidt, J., Sharma, S., Starik, M., Eds.; Sustainable Innovation and Entrepreneurship; Edward Elgar: Cheltenham, UK, 2008.

65. Tietenberg, T.H., Ed.; Innovation in Environmental Policy: Economic and Legal Aspects of Recent Developments in Environmental Enforcement and Liability; Aldershot: Hants, UK, 1992.

66. Corral, M.C. Environmental Policy and Technological Innovation: Why Do Firms Adopt or Reject New Technologies; Edward Elgar: Cheltenham, UK, 2003.

67. Jordan, A.J., Lenschow, A., Eds.; Innovation in Environmental Policy? Integrating the Environment for Sustainability; Edward Elgar: Cheltenham, UK, 2008.

68. Sartorius, C., Zundel, S., Eds.; Time Strategies, Innovation and Environmental Policy; Edward Elgar: Cheltenham, UK, 2005.

69. New Zealand Council of Trade Unions. Unions, Innovation and Sustainable Development; New Zealand Council of Trade Unions: Wellington, New Zealand, 2002.

70. Horbach, J., Ed.; Indicator Systems for Sustainable Innovation; Physica-Verlag: Heidelberg, Germany, 2005.

71. Dijkema, G.P.J.; Ferrão, P.; Herder, P.M.; Heitor, M. Trends and Opportunities Framing Innovation for Sustainability in a Learning Society. Technol. Forecast. Soc. 2006, 73, 215-227.

72. Kok, M.T.J., Vermeulen, W., Faaij, A., de Jager, D., Eds.; Global Warming and Social Innovation: The Challenge of a Climate-Neutral Society; Earthscan: London, UK, 2002.

73. Goudas, C.L., Katsiaris, G., May, V., Karambas, T., Eds.; Soft Shore Protection: An Environmental Innovation in Coastal Engineering Science; University of Patras: Patras, Greece, 2001.

74. Davidson, J.; Lockwood, M. Partnerships as Instruments of Good Regional Governance: Innovation for Sustainability in Tasmania? Reg. Stud. 2008, 42, 641-656.

75. OECD. Regions Matter: Economic Recovery, Innovation and Sustainable Growth; OECD: Paris, France, 2009. 
76. Velasquez, J., Yashiro, M., Yoshimura, S., Ono, I., Eds.; Innovative Communities: People-centred Approaches to Environmental Management in the Asia-Pacific Region; United Nations University Press: Tokyo, Japan, 2005.

77. Steger, U.; Achterberg, W.; Blok, K.; Bode, H.; Freuz, W.; Gather, C.; Hanekamp, G.; Imboden, D.; Jahnke, M.; Kost, M.; et al. Sustainable Development and Innovation in the Energy Sector; Springer: Berlin, Germany, 2005.

78. Praetorius, B.; Bauknecht, D.; Cames, M. Innovation for Sustainable Electricity Systems: Exploring the Dynamics of Energy Transitions; Physica-Verlag: Heidelberg, Germany, 2008.

79. OECD. Innovation and the Environment; OECD: Paris, France, 2000.

80. Hayter, R., Le Heron, R., Eds.; Knowledge, Industry and Environment: Institutions and Innovation in Territorial Perspective; Ashgate: Aldershot, UK, 2002.

81. Hines, F.; Marin, O. Building Innovations for Sustainability: 11th International Conference of the Greening of Industry Network. Business Strategy Environment 2004, 13, 201-208.

82. Freeman, C. Green Technology and Models of Innovation. Technol. Forecast. Soc. 1996, 53, 27-39.

83. Placet, M.; Anderson, R.; Fowler, K.M. Strategies for Sustainability. Res. Technol. Manage. 2005, 48, 32-41.

84. Maxwell, I.E. Managing Sustainable Innovation: The Driver for Global Growth; Springer: New York, NY, USA, 2009.

85. Thompson, V. Bureaucracy and Innovation. Admin. Sci. Quart. 1965, 10, 1-20.

86. Moore, M.H. Creating Public Value: Strategic Management in Government; Harvard University Press: Cambridge, MA, USA, 1995.

87. Moore, M.H. Break-through Innovations and Continuous Improvement: Two Different Models of Innovative Processes in the Public Sector. Public Money Manage. 2005, 25, 43-50.

88. Borins, S. Innovating with Integrity: How Local Heroes are Transforming American Government; Georgetown University Press: Washington, DC, USA, 1998.

89. Benington, J. The Modernization and Improvement of Government and Public Services. Public Money Manage. 2000, 20, 3-8.

90. Albury, D. Fostering Innovation in Public Services. Public Money Manage. 2005, 25, 51-56.

91. González, S.; Healey, P. A Sociological Institutionalist Approach to the Study of Innovation in Governance Capacity. Urban Studies 2005, 42, 2055-2069.

92. Moore, M.H.; Hartley, J. Innovations in Governance. Public Management Review 2008, 10, 3-20.

93. Windrum, P., Koch, P., Eds.; Innovation in Public Sector Services: Entrepreneurship, Creativity and Management; Edward Elgar: Cheltenham, UK, 2008.

94. Rashman, L.; Hartley, J. Leading and Learning? Knowledge Transfer in the Beacon Council Scheme. Public Admin. 2002, 80, 523-542.

95. Rogers, E.M. Diffusion of Innovations, 5th Ed; Free Press: New York, NY, USA, 2003.

96. Rhodes, R.A.W. The New Governance: Governing without Government. Political Studies 1996, 44, 652-667.

97. Rhodes, R.A.W. Understanding Governance: Policy Networks, Governance, Reflexivity and Accountability; Open University Press: Buckingham, UK, 1997.

98. Stoker, G., Ed.; The New Politics of Local Governance; Macmillan: London, UK, 2000. 
99. Cars, G., Healey, P., Madanipour, A., de Magalhaes, C., Eds.; Urban Governance, Institutional Capacity and Social Milieux; Ashgate: Aldershot, UK, 2002.

100. Newman, J. Modernising Governance. New Labour, Policy and Society; Sage: London, UK, 2001.

101. Bang, H.P., Ed.; Governance as Social and Political Communication; Manchester University Press: Manchester, UK, 2003.

102. Boyte, H.C. Reframing Democracy: Governance, Civic Agency, and Politics. Public Admin. Rev. 2005, 65, 536-546.

103. Hill, C.; Lynn, L. Is Hierarchical Governance in Decline? Evidence from Empirical Research. $J$. Public Admin. Res. Theory 2005, 15, 173-195.

104. Kooiman, J. Governing as Governance; Sage: London, UK, 2003.

105. Healey, P. Creativity and Urban Governance. Policy Studies 2004, 25, 87-102.

106. Chapin, FS.; Carpenter, S.R.; Kofinas, G.P.; Folke, C.; Abel, N.; Clark, W.C.; Olsson, P.; Smith, D.M.S.; Walker, B.; Young, O.; et al. Ecosystem Stewardship: Sustainability Strategies for a Rapidly Changing Planet. Trends Ecol. Evol. 2009, 25, 241-249.

107. Underdal, A. Complexity and challenges of long-term environmental governance. Global Environ. Change 2010, 20, 386-393.

108. Lebel, L.; Anderies, J.M.; Campbell, B.; Folke, C.; Hatfield-Dodds, S.; Hughes, T.P.; Wilson, J. Governance and the Capacity to Manage Resilience in Regional Social-Ecological Systems. Ecol. Soc. 2006, 11, 19.

109. Lemos, M.C.; Agrawal, A. Environmental Governance. Annu. Rev. Environ. Res. 2006, 31, $297-325$.

110. Ostrom, E.; Burger, J.; Field, C.B.; Norgaard, R.B.; Policansky, D. Revisiting the Commons: Local Lessons, Global Challenges. Science 1999, 284, 278-282.

111. Coafee, J.; Healey, P. "My voice: My place": Tracking Transformations in Urban Governance. Urban Studies 2003, 40, 1979-1999.

112. Healey, P. Transforming Governance: Challenges of Institutional Adaptation and a New Politics of Space. Eur. Plan. Stud. 2006, 14, 299-320.

113. Novy, A.; Leubolt, B. Participatory Budgeting in Porto Alegre: Social Innovation and the Dialectical Relationship of State and Civil Society. Urban Studies 2005, 42, 2023-2036.

114. Moulaert, F.; Martinelli, F.; González, S.; Swyngedouw, E. Between Path Dependency and Radical Innovation Introduction: Social Innovation and Governance in European Cities: Urban Development. Eur. Urban Reg. Stud. 2007, 14, 195-209.

115. Novy, A.; Hammer, E. Radical Innovation in an Era of Liberal Governance: The Case of Vienna. Eur. Urban Reg. Stud. 2007, 14, 210-222.

116. Swyngedouw, E. Governance Innovation and the Citizen: The Janus Face of Governancebeyond-the-State. Urban Studies 2005, 42, 1991-2006.

117. Cooke, B., Kathari, U., Eds.; Participation: The New Tyranny? Zed Books: New York, NY, USA, 2001.

118. Hickey, S., Mohan, G., Eds.; Participation: From Tyranny to Transformation? Zed Books: New York, NY, USA, 2004; p. 292. 
119. Gerometta, J.; Häussermann, J.; Longo, G. Social Innovation and Civil Society in Urban Governance: Strategies for an Inclusive City. Urban Studies 2005, 42, 2007-2021.

120. Folke, C.; Pritchard, L.; Berkes, F.; Colding, J.; Svedin, U. The Problem of Fit between Ecosystems and Institutions: Ten Years Later. Ecol. Soc. 2007, 12, 30.

121. Brondizio, E.S.; Ostrom, E.; Young, O.R. Connectivity and the Governance of multi-level socialecological systems: The role of Social Capital. Annu. Rev. Env. Resour. 2009, 34, 253-278.

122. Pahl-Wostl, C. A Conceptual Framework for Analysing Adaptive Capacity and Multi-level Learning Processes in Resource Governance Regimes. Global Environ. Change 2009, 19, 354-365.

123. Pelletier, N. Of Laws and Limits: An Ecological Economic Perspective on Redressing the Failure of Contemporary Environmental Governance. Global Environ. Change 2010, 20, 220-228.

(C) 2013 by the authors; licensee MDPI, Basel, Switzerland. This article is an open access article distributed under the terms and conditions of the Creative Commons Attribution license (http://creativecommons.org/licenses/by/3.0/). 